\title{
OSIOŁ KYLEŃSKI
}

\section{GIORDANO BRUNO}

\section{Osoby: Osioł, Micco Pitagorejczyk, Merkury}

Osioł - Dlaczegóż miałbym rzekomo nadużyć tak wspaniałego, wyjątkowego i niespotykanego daru twego, o gromowładny Jowiszu? Dlaczegóż miałbym dany mi od ciebie talent, który wyróżnia mnie w twych oczach, chować pod czarna glebą niewdzięcznego milczenia? Czy miałem dalej cierpieć napór cisnących się słów, by nigdy nie dać im wyjść z mego pyska? Czy ten nadzwyczajny ryk, którym onegdaj, w pełnych zamętu czasach, zapłodniłeś mego ducha, miałoby w nim pozostać? Niechże raczej klucz nadarzającej się okazji otworzy pałac oślej mowy i naglony tematem niech rozwiąże się mój język! Niechaj dłoń uwagi, wiedziona ramieniem zamysłu zerwie owoc i kwiat rosnące w ogrodzie oślej pamięci.

Micco $^{1}$ - O niesłychany wybryku! O dech zapierający dziwie! O niewiarygodna cudowności! O zadziwiające zjawisko! Czy bogowie nie mogliby przepędzić tej okropności? Osioł, który gada? O Muzy, o Apollinie, o Herkulesie! Czy to z tej oślej gęby dochodzą owe głosy? Och, zamilcz, Micco, bo pewnie się mylisz! Wszak to pewnie człowiek, który chce nas wykpić, ukrył się pod tą skórą.

\footnotetext{
${ }^{1}$ Należy zauważyć, że micco w języku włoskim oznacza „głupi” lub „krótkowzroczny” (przyp. red.).
} 
Osioł - Uwierz, Micco, że nie jestem wcale sztucznym, ale jak najbardziej naturalnym osłem, który mówi. I tak jak pamiętam, że kiedyś miałem ciało ludzkie, tak teraz, jak widać, mam członki zwierzęcia.

Micco - Później, wcielony demonie, zapytam cię, kim jesteś, czym jesteś i jakżeś zrobiony wpierw chcę jednak wiedzieć, co to za sprawa cię tu przygnała. Co za zaklęcie cię tu sprowadziło? Z jaką wiadomością przysyłają cię bogowie? I jak zakończyć się ma ta scena? Po co kopyta twoje przyniosły cię aż pod nasz portyk, gdzie w sposób tak szczególny czynisz użytek ze swej mowy?

Osioł - Dowiedz się więc wprzódy, że pragnę zostać członkiem, a także doktorem szkoły albo akademii, aby doceniono moje zdolności, aby przestano uznawać moje opinie za gorsze i lekceważyć moje słowa, i z nieufnością słuchać mojej nauki tylko dlatego...

Mico - O Jowiszu! Czyś ab aeterno ${ }^{2}$ widział fakt, zdarzenie bądź przypadek taki, jak ten tutaj?

Osioł - Przestańże się na chwilę dziwić i odpowiedz mi zaraz, ty, albo któryś z tych, co się tu zbiegli i słuchaja mnie osłupiali. Wy, którzy nosicie togi, pierścienie, birety dydaktyków i arcydydaktyków, herosi i półbogowie wiedzy, czy zechcielibyście się zgodzić na to, by do waszego stowarzyszenia, pod flagę i sztandar waszej wspólnoty włączyć i mnie, osła, którego oto widzicie i słuchacie? Dlaczegóż jedni z was dziwią się śmiejąc, inni śmieją się dziwiąc, a inni jeszcze - których jest najwięcej - stoją w osłupieniu, przygryzając wargi? I dlaczego żaden $\mathrm{z}$ was nie odpowiada?

Micco - Sam widzisz, że to stupor zamkną im usta. Odwracają się do mnie i posyłają mi znaki, abym to ja ci odpowiadał. Do mnie, jako do przewodniczącego, należy powiadomić cię, co uradziliśmy, i to ja, jako przedstawiciel nas wszystkich, powiem ci o naszej opinii.

Osioł - Cóż to za akademia, na której drzwiach napisano: Lineam ne pertransito3?

Micco - To szkoła pitagorejczyków.

Osioł - Czy można tam wejść?

Micco - Tylko jako jej członek i nie bez spełnienia wielu wymagających warunków.

Osioł - Cóż to za warunki?

Micco - Są one bardzo liczne.

Osioł - Pytałem cię, jakie są te warunki, a nie ile ich jest.

\footnotetext{
2 Kiedykolwiek wcześniej, od początku istnienia świata (przyp. red.).

${ }^{3}$ Nie przekraczaj linii (przyp. red.).
} 
Micco - Odpowiem ci najlepiej, wymieniając tylko najważniejsze. Po pierwsze: ten, kto chce być członkiem akademii, musi dać się nam zbadać pod względem zdolności swego ciała, swej fizjonomii i temperamentu, przez wzgląd na głęboką zależność, jaka ciało łączy z duszą i na odwrót.

Osioł - Ab Iove principium Musae.4, skoro zechciał się żenić.

Micco - Po drugie: dla każdego przyjętego ustala się pewien okres - długości lat minimum dwóch - podczas którego ma milczeć, i nie pozwala się, by ważył się choćby pytać, nawet wtedy, gdy czegoś nie pojął, tym bardziej zaś wyklucza się, by dyskutował lub sam roztrząsał jakiekolwiek zagadnienie. W okresie tym adepta nazywa się „akuzmatykiem” (,acustico”). Po trzecie: gdy upłynie wyznaczony czas, pozwala się mu mówić, dopytywać i zapisywać, co zrozumiał, i wyrażać swoje własne opinie - nazywany jest wtedy „matematykiem” lub „chaldejczykiem” (,caldeo”). Po czwarte: kiedy z rzeczami tymi jest już zaznajomiony i dzięki studiom swym zorientowany, przejść może do lektury księgi świata i badania zasad natury. To jego punkt dojścia, gdzie nadany mu zostaje tytuł „fizyka”.

Osioł - I dalej się już nie idzie?

Micco - Nie, możemy zostać najwyżej fizykami, ponieważ nie da się zdać sprawy z rzeczy nadnaturalnych inaczej, jak tylko o tyle, o ile mają one odbicie w rzeczach naturalnych. Tylko wyższy, czysty intelekt może pojąć je same w sobie.

Osioł - Nie uprawia się więc u was metafizyki?

Micco - Nie, a to, co inni uważają za metafizykę, nie jest niczym innym jak dziedzina logiki. Zostawmy to jednak, bo nie o tym rozmawiamy. Podsumowując - usłyszałeś właśnie, jakie są warunki i reguly naszej akademii.

Osioł - I to tyle?

Micco - Tak, mój Panie.

Osioł - O szacowna szkoło, o wspaniała uczelnio, o przebogate grono, o czcigodne kolegium, oświecony gimnazjonie, szkoło niezwyciężona i akademio pierwsza między pierwszymi! Osioł błądzący, jak spragniony wody jeleń, zwraca się do was niczym ku czystemu i orzeźwiającemu źródłu. Ja, skromny i pokorny osioł, przedstawiam się wam, dobroczyńcy pielgrzymujących, i pragnę stać się członkiem waszego towarzystwa.

Micco - Co? Członkiem naszego towarzystwa?

\footnotetext{
${ }^{4}$ Osioł cytuje fragment trzeciej Bukoliki Wergiliusza. W przekładzie Józefa Lipińskiego brzmi on tak:

„Początek od Jowisza: on wszystko zapienia,

On ziemi daie żyźność, moie kształci pienia”

Publiusz Wirgiliusz Maron, Bukoliki, przeł. Józef Lipiński, Warszawa 1805, s. 17.
} 
Osioł - Tak, tak, Wielmożny Panie, członkiem waszego towarzystwa.

Micco - Wejdź jednak innymi drzwiami, mój Panie, te nie są przeznaczone dla osłów.

Osioł - A ty, mój bracie, których używasz?

Micco - Może i rzeczywiście niebiosa zdolne są sprawić, by osły gadały, ale na pewno nie zrobią z nich uczniów pitagorejczyków.

Osioł - Nie bądź tak wyniosły, Micco, i przypomnij sobie, czego nauczał twój Pitagoras nauczał on bowiem, że nic, co zrodzone z łona natury, nie zasługuje na pogardę. Moja teraźniejsza, ośla postać nie wyklucza, że niegdyś mogłem lub niedługo będę mógł przybrać formę rosłego mężczyzny; także ty - choć teraz jesteś człowiekiem - mogłeś i niedługo znów będziesz mógł stać się wielkim osłem, jeśli za właściwe uzna to ten, który rozdziela zdolności, przyznaje miejsca i zawiaduje wędrującymi duszami

Micco - Powiedz mi, bracie, czyś pojął, jakie wymagania i dyrektywy obowiązuja w naszej akademii?

Osioł - Pojąłem bardzo dobrze.

Micco - Co byś jednak powiedział, gdyby jakimś trafem, z uwagi na ten czy inny twój defekt, odmówiono ci wstępu?

Osioł - Wierzę, że miałbym wiele do powiedzenia.

Micco - Zamieniamy się w słuch.

Osioł - Pierwszym, co wywołuje moje wątpliwości, jest wasz warunek zasadniczy. Prawda, że nie mam z natury tak powabnej cielesności i tak miękkiej, gładkiej i delikatnej skóry, które zdaniem fizjonomistów lepiej służą recepcji nauk, ponieważ to, co twarde, nie idzie w parze ze sprawnością intelektu. Wydaje mi się jednak, że przewodniczący mógłby mi udzielić w tej kwestii dyspensy, nie powinno się bowiem odrzucać kogoś w przypadku, gdy mankament taki rekompensuje wiele innych zalet: wiarygodność jego obyczajów, żywotność inteligencji i sprawność rozumu, oraz inne dyspozycje będące siostrami, córkami bądź towarzyszkami zalet powyższych. Nie powinno się również uznawać za powszechnie obowiązujące mniemania, zgodnie z którym dusze naśladuja złożoność ciał (la complession del corpo); możliwe jest bowiem, że jakaś potężniejsza duchowa zasada zdoła zwyciężyć i unieważnić ujmę, jaką czyni jej szkaradność ciała lub inna niedyspozycja. W tym temacie wystarczy chyba przypomnieć wam przykład Sokratesa, który zdaniem fizjonomisty Apfyrosa miał być nieumiarkowany, głupawy, zniewieściały, niestateczny i wykazywać skłonności wobec małych dzieci. Filozof nie wypierał się posiadania tych przymiotów, co nie znaczy jednak, że inklinacjom swym folgował. Przeciwnie, nieustanne ćwiczenia w filozofii pozwoliły mu je ujarzmić i, rzec by można, włożyły mu w dłonie pewny ster, dzięki któremu manewrował i unikał gwałtownych 
prądów swych przyrodzonych słabości, tak że nie było niczego, czego by nie mógł swą nauką zwyciężyć. Po drugie, jeśli przypadek mój rozważyć w świetle innego rozumienia fizjonomii, to znaczy nie tego, które bada złożoność temperamentów, ale tego zorientowanego na harmonijną proporcję członków, to zapewniam was, że jeśli tylko dobrze będziecie patrzeć, nie wytkniecie mi żadnego w tej kwestii defektu. Wiecie bowiem, że nie idzie o to, aby świnia była pięknym koniem, a osioł przystojnym mężczyzną. Chodzi o to jedynie, by osioł był ładnym osłem, świnia ładną świnia, a człowiek ładnym człowiekiem. Rozumując dalej w ten sposób, stwierdzić można, że koń nie wyda się nigdy nazbyt pięknym z punktu widzenia świni, dokładnie tak jak świnia nie olśni swą urodą konia; jeśli osioł nie wydaje się człowiekowi piękny i nie sprawia, że ten zaczyna pałać do niego miłością, to zapewniam was, że także człowiek nie wydaje się piękny osłu i wcale nie rozkochuje go w sobie. Kiedy więc zgodnie $\mathrm{z}$ tym prawem rzeczy zostaną zmierzone i zbadane w sposób rozumny, jedno przyzna drugiemu, w zgodzie $\mathrm{z}$ naturą swoich własnych afektów, że różnorakie istnieją piękna, tak jak różne są sposoby postrzegania proporcji, i że żadna ani żaden nie sa piękni niezaprzeczalnie i absolutnie, bo takie jest tylko piękno samo i to, czego piękno jest istotą, a nigdy to, co w pięknie ma pewien tylko udział. Przemilczę tymczasem fakt, że jeśli chodzi o ludzkie ciała, sądy tego rodzaju wydawać należy respectu babito ${ }^{5}$ dla dwudziestu pięciu okoliczności i zastrzeżeń, w których tkwi cały niuans. Jeszcze inaczej mówiąc, reguła fizjonomiczna, która za wytyczną bierze cielesną miękkość, okazuje się fałszywa, chyba że niemowlęta lepiej predysponowane są do nauk niż dorośli, a kobiety lepiej od mężczyzn, i chyba że największą zdolność zdefiniujemy jako możność najbardziej oddaloną od aktu.

Micco: Jak dotychczas przemawia on z wielką wiedzą. Kontynuuj, panie Ośle, i nie wahaj się olśniewać nas dalej brawurą swych argumentów, gdyż:

\section{Zawracasz kijem rzekę i w piachu ziarno siejesz \\ I wierzysz, że wiatr zrywny złapiesz w swoje sieci \\ Lecz tylko serca niewiast albo małych dzieci \\ Żywić mogą takie nadzieje}

Podobnej natury jest i twoja wiara, jeśli rzeczywiście sądzisz, że panowie akademicy, w tej czy jakiejkolwiek innej szkole, mieliby ci przyznać w niej miejsce. Ale jeśliś tak uczony, to raduj się swą doktryną do woli. Byle w samotności.

\footnotetext{
${ }^{5}$ Z szacunkiem (przyp. red.).
} 
Osioł - O bezmyślni! Uważacie, że przedstawiam wam swoje argumenty tylko po to, by zyskać wasze uznanie? Myślicie, że chodziło mi o co innego, niż by zdemaskować wasze wymówki i postawić was przed sądem Jowisza? Jowisz, który uczynił mnie uczonym, już dawno zrobił ze mnie doktora. Czekałem tylko na to, by któryś z was w swej próżności chlapnął tę sakramentalną sentencję: „Nie godzi się, aby osły wchodziły do naszej akademii razem z nami, ludźmi”. Pierwszy lepszy mędrek może mówić takie rzeczy, ale nie wy, pitagorejczycy - ponieważ odmawiając mi prawa wstapienia do waszej szkoły, obracacie wniwecz zasady, założenia i z nimi cały korpus waszej filozofii. Jakąż to różnicę znajdujecie między nami, osłami, i wami, ludźmi, skoro nie oceniacie podobno rzeczy wedle ich powierzchowności i wyglądu? Ponadto, wyznajcie mi szczerze, nieudolni sędziowie, ilu z was trenowało w akademii osłów? Ilu z was dalej uczęszcza na lekcje w oślej szkole? Ilu z was wciąż czerpie korzyści z jej nauczania? Ilu z was mianowano doktorami oślej akademii? Ilu z was utkwiło jak kołki w szkole osłów i ilu z was w niej umrze? Ilu z was wybrała, wyniosła, wysławiła, kanonizowała, uświęciła i wreszcie ubóstwiła ośla szkoła? I jeśli ci, o których mowa, nie byliby osłami lub nie byliby się nimi stali, nie wiem zaprawdę, jak potoczyłyby się ich losy i jak w ogóle mogłyby się one potoczyć. Czyż nie sa liczne uniwersytety, i to te najbardziej uznane i światłe, gdzie nie tylko dla doczesnego dobrobytu, ale także dla celów wieczności naucza się, jak zośleć? Powiedzcie mi, do jakich talentów i zaszczytów bram nie otwiera bycie osłem? Przyznajcie, iluż zostało pozbawionych swych honorów, wykluczonych, odtrąconych i przeklętych właśnie dlatego, że nie zdołali posiąść oślich cnót i zdolności? Dlaczegóż więc miałoby być niedopuszczalnym, aby pewna liczba osłów lub przynajmniej jeden z nich wstąpił do akademii ludzi? Dlaczego nie mogę zostać przyjęty dzięki większości przychylnych mi głosów do którejkolwiek ze szkół, podczas gdy imiona przeważającej większości głosujących, jeśli nie wszystkich, wyryte są na ścianach naszej, tak uniwersalnej akademii? I jeśli my, osły, jesteśmy wystarczająco gościnne i szczodre, by przyjmować wszystkich, dlaczego wy tak strasznie wzdragacie się na myśl, że moglibyście przyjać choćby jednego z nas?

Micco - Więcej trudności wymagają bowiem sprawy ważne i godne. Zgodnie z tą samą zasadą nikt nie robi sobie kłopotu i nie poświęca uwagi rzeczom bez wartości. To, że osły przyjmują do swojej szkoły kogo popadnie, wcale nie znaczy, że tak samo ma być w akademii ludzi.

Osioł - Możecie mi jednak powiedzieć, mój Panie, który z nich bardziej jest godny: człowiek, który zoślał, czy osioł, co się uczłowieczył? Cóż to jednak - czyżby nadciągał mój Kylleńczyk? Tak, widzę kaduceusz i rozpoznaję jego skrzydła! Witaj wspaniała skrzydlata istoto! Posłańcu Jowisza, wierny egzegeto woli wszystkich bogów, szczodry dostarczycielu wiedzy, inspiratorze sztuk, wieczna wyrocznio matematyków, uwielbiany arytmetyku, wytworny mówco, wspaniałe oblicze, figuro pełna wyrazu i gracji, mężu pośród mężów, 
niewiasto pośród niewiast, znieważany pośród znieważanych, szczęśliwy pośród szczęśliwych, wszelaki we wszystkim! Rozweselasz się z tymi, którzy się weselą, płaczesz z płaczącymi, w ten sposób wszędzie, gdzie przybywasz, mile jesteś widziany i dobrze przyjęty, a przybyć możesz wszędzie. Co dobrego przynosisz?

Merkury - Ośle, jeśli chcesz przyjąć status i tytuł akademika, ja, który udzieliłem ci już innych darów i łask, na mocy mojego autorytetu zarządzam, ustanawiam i mianuję cię akademikiem, biegłym w każdej doktrynie, abyś mógł wchodzić i przebywać wszędzie, i aby nikt nie mógł zabronić ci wejścia, ani czynić ci jakichkolwiek wymówek i w czymkolwiek cię powstrzymywać, quibuscumque in oppositum non obstantibus ${ }^{6}$. Wchodź więc tam, gdzie uważasz, że dobrze jest wchodzić. Nie chcemy też, abyś zgodnie z pitagorejskim regulaminem poddany był regule dwuletniego milczenia ani żadnej innej zwyczajowej regule: ponieważ novis intervenientibus causis, novae condendae sunt leges, proque ipsis condita non intelliguntur iura: interimque ad optimi iudicium iudicis referenda est sententia, cuius intersit iuxta necessarium atque commodum providere ${ }^{7}$. Przemawiaj więc pośród akuzmatyków, roztrząsaj i kontempluj wśród matematyków, dyskutuj, kwestionuj, nauczaj, deklaruj i ustalaj wśród fizyków. Odnajduj się wśród wszystkich, ze wszystkimi rozmawiaj, brataj i jednocz się z wszystkimi, utożsamiaj z wszystkimi, nad wszystkimi dominuj, bądź wszystkim.

Osioł - Słyszeliście, co powiedział?

Micco - Nie jesteśmy głusi.

\footnotetext{
${ }^{6}$ By nikt, kto się przeciwstawia, nie był przeszkodą (przyp. red.)

${ }^{7}$ Dla nowych przyczyn, nowe ustalane są prawa, nie da się ich bowiem pojąć wedle praw dawnych. Wtedy najlepsi z sędziów ustalić powinni werdykt, musi on się bowiem zgadzać z tym, co konieczne, jak i z tym, co korzystne. (przyp. red.).
} 
Giordano Bruno - filozof renesansowy urodzony w 1548 we włoskiej Noli. W 1559 roku przenosi się do Neapolu, gdzie podejmuje studia (trivium), następnie zaś wstępuje do zakonu dominikanów, by w 1575 uzyskać tytuł doktora teologii na podstawie rozprawy o Tomaszu z Akwinu i Piotrze Lombardzie. Rok później porzuca zakon i zaczyna wieloletnią wędrówkę, najpierw po licznych miastach włoskich, następnie trafia do hrabstwa Sabaudzkiego, Genewy (gdzie zostaje aresztowany i ekskomunikowany), Lyonu, Tuluzy, skąd po wydaniu traktatu mnemotechnicznego Clavis Magna zaproszony zostaje na dwór Henryka III. W 1583 roku udaje się Bruno do Londynu, publikuje tam swe najważniejsze dzieła. Powraca do Paryża, by zaraz znów musieć uciekać, tym razem do Niemiec. Tu kolejne publikacje i wystapienia sprowadzaja nań ekskomunikę, tym razem ze strony Kościoła luterańskiego. W nie do końca jasnych okolicznościach powraca do Wenecji, gdzie zostaje aresztowany przez inkwizycję. Więzienie i proces trwają osiem lat, po których 17 lutego 1600 Bruno zostaje spalony na stosie na rzymskim Campo de’Fiori, gdzie znajduje się dziś jego pomnik. Zachowała się tylko część obszernej dokumentacji procesu; również nie wszystkie dzieła Bruna doczekały naszych czasów. Mimo oficjalnego potępienia i zakazu publikacji jego idee wywarły silny wpływ na późniejszą filozofię, między innymi Leibniza, Spinozę i Schellinga.

CYTOWANIE: Bruno, Giordano. 2016. Osioł kyleński. Praktyka Teoretycæna 1(19): 68-75.

DOI: $10.14746 /$ prt.2016.1.5

AUTHOR: Giordano Bruno

TITLE: Cyllenian Donkey 